\title{
Analysis of Potential Biogas Production from a Mixture of Palm Oil Mill Effluent (POME) and Cow Dung
}

\author{
Tiyo Agung Pambudi ${ }^{1 ' *)}$ Hadiyanto $^{1 / 2)}$ and Sri Widodo Agung Suedy 1'3) \\ ${ }^{1}$ Master Program of Energy, School of Postgraduate Studies, Diponegoro University, Semarang, \\ 50275, Indonesia. \\ ${ }^{2}$ Department of Chemical Engineering, Faculty of Engineering, Diponegoro University, Semarang, \\ 50275, Indonesia. \\ ${ }^{3}$ Department of Biology, Faculty of Science and Mathematics, Diponegoro University Semarang, \\ 50275, Indonesia.
}

\begin{abstract}
POME or palm oil mill effluent is currently still a waste problem that has not been utilized optimally. POME waste has the potential for renewable energy in the form of biogas, but some research results have shown that production is not optimal, so the addition of cow dung needs to be done to increase biogas production because methanogen bacteria found in cow dung help to maximize the anaerobic fermentation process and methane production. This research was conducted to determine the potential for biogas production from a mixture of POME and cow dung for 25 days by conducting a study of the biogas production process. The results of this study indicate that the biogas pressure increases with the addition of the loading rate, which is $101.102 \mathrm{~N} / \mathrm{m}^{2} /$ day to $101.107 \mathrm{~N} / \mathrm{m}^{2} /$ day with a daily biogas production of 0,24247 liters/day with a total accumulation of biogas production for 25 days of 6.1 liters.
\end{abstract}

\section{Introduction}

Palm oil is currently the largest source of vegetable oil in the world. Palm oil contributes about $27 \%$ or 46 million tons of total vegetable oil globally [1]. Palm oil is one of the most consumed and produced oils in the world. Indonesia is one of the largest producers and exporters of palm oil in the world. The increase in demand for Crude Palm Oil (CPO) has prompted a long-term plan for CPO production of 49 million tons/year in 2021[2]. In the process, the palm oil industry produces several types of waste in solid and liquid waste. The most crucial liquid waste from the palm oil industry is Palm Oil Mill Effluent (POME) (figure 1). For every 1 tonne of CPO, about 5-7.5 tons of water are needed, and more than $50 \%$ of the water used in CPO production will end up as liquid waste [3]. POME waste that comes out of the treatment process usually has a high temperature, which is in the range of 70$800^{\circ} \mathrm{C}$, with an acidity level $(\mathrm{pH})$ of around $4.56-4.98$, COD (Chemical Oxygen Demand) ranging from 57,000-60,400 mg/liter and Total Suspended Solid (TSS) $0.23-5.44 \mathrm{~g} / \mathrm{L} \mathrm{[4].}{ }^{1}$

\footnotetext{
*Corresponding author: agungtiyo49@gmail.com
} 


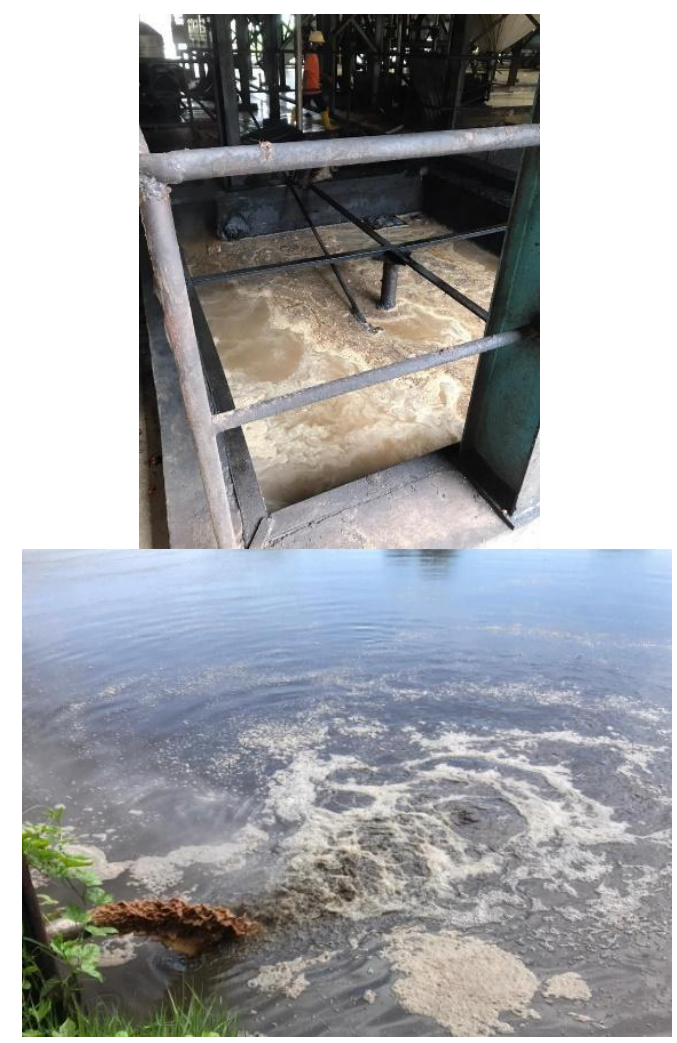

Fig. 1. Liquid waste from the $\mathrm{CPO}$ production process.

POME is not toxic but can pollute the environment because it can reduce the dissolved oxygen content in the water [5]. The most conventional palm oil wastewater treatment process is to leave the POME in a pond to decompose naturally by microbes. However, this process produces a by-product in the form of biogas, which will contribute significantly to air pollution and greenhouse gases if released into the air. Therefore, the best treatment for effluent that has a high organic content is anaerobic treatment. Anaerobic processes are one of the most energy-efficient and environmentally friendly technologies for bioenergy production [4]. While the role of cow dung is as a source of methanogen bacteria and as a good source of inoculum for methanogen microorganisms in the formation of biogas, these microorganisms can work optimally to increase biogas production. Both of these wastes can be used as raw materials for the manufacture of alternative energy, one of which is biogas. This biogas production can be used as an alternative fuel for the palm oil processing industry. In contrast, the by-product of the biogas production process can be used as organic liquid fertilizer.

\section{Methodology}

\subsection{Experimental Area}

The experimental location was carried out on a household scale, starting with the taking of raw materials in the form of POME at the Palm Oil Mill in Siak Regency, Riau Province, Indonesia, and followed by taking cow dung every day during the study at beef cattle farms in the village around the palm oil processing factory. The bio-digester used in this study is a 
fixed dome type with a total capacity of 120 liters (figure 2). The fixed domed plant typically consists of a digester with a gas reservoir at the top of the digester. When the gas appears, it presses the remaining fermented slurry (slurry) into the slurry tank. If the supply of manure is continuous, the gas generated will continue to press the slurry until it overflows out of the slurry tank. [6]

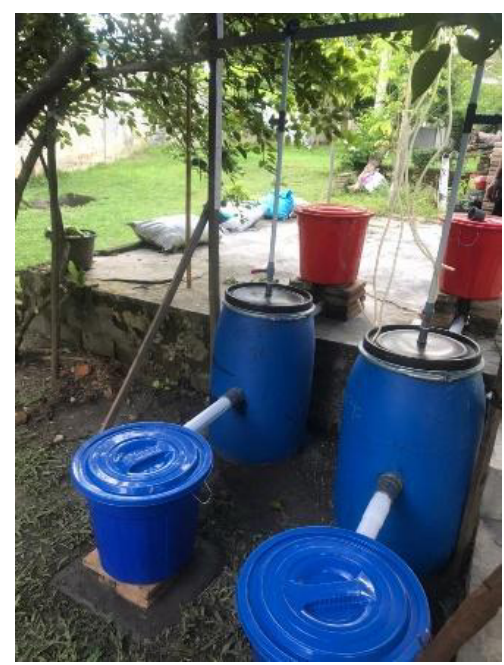

Fig. 2. Bio-digester fixed dome type.

\subsection{Experimental Procedures}

In this experiment, the initial stage is the acclimatization process by entering POME into the bio-digester originating from the palm oil mill wastewater treatment pond and observing changes in $\mathrm{pH}$ and temperature produced. The second stage is the biogas production process by feeding cow dung which is carried out in each bio-digester. Comparison of treatment and loading rate between a mixture of POME and cow dung added to the bio-digester, namely $50 \%$ POME and 50\% cow dung solution with different loading rates with variations of $1 \mathrm{~L} /$ day and $2 \mathrm{~L} /$ day. A mixture of POME and cow dung solution is done by reducing the substrate as much as the volume to be inserted. The third stage is observing the measurement of temperature, $\mathrm{pH}$, and analysis of biogas production.

\section{Result and discussion}

\subsection{Analysis Temperature}

The temperature influences the process of converting organic matter into biogas. The influence is related to the activity and process of microbial growth in the bio-digester. It is essential to measure the temperature every day to determine the conditions in the digester (figure 3). 


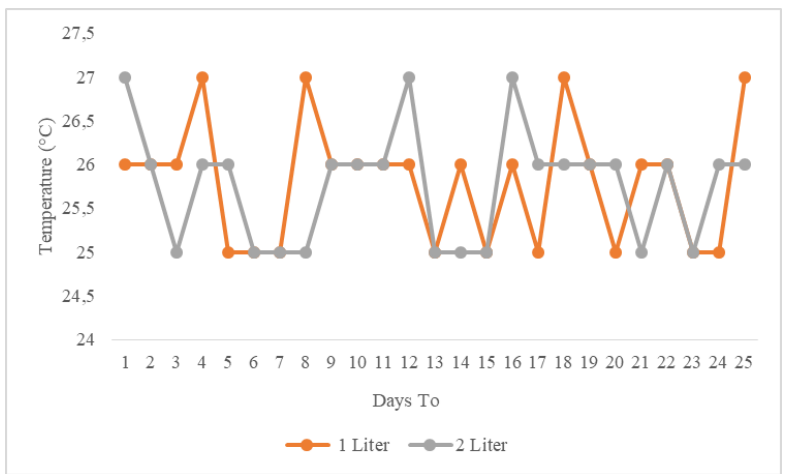

Fig. 3. Graph of temperature inside the bio-digester.

The temperature range in the bio-digester achieved by all treatments with the addition of 1 and 2 liters of loading was between $25-27^{\circ} \mathrm{C}$. The temperature achieved during the biogas production process is below the mesophilic temperature $\left(30-40{ }^{\circ} \mathrm{C}\right)$. This does not affect the occurrence of the methanogenesis process because the methanogenesis process can still occur. The minimum temperature for bacteria to grow during the anaerobic fermentation process, especially in the unheated biodigester, is $15{ }^{\circ} \mathrm{C}$ [7]. Bio-digester operating at temperatures below $15^{\circ} \mathrm{C}$ only get a limited amount of biogas, which is very uneconomical.

\subsection{Analysis $\mathrm{pH}$}

Analysis of $\mathrm{pH}$ value is one of the factors that affect the fermentation process in biogas production. Natural bacteria that decompose organic matter can develop well in slightly acidic conditions, and the $\mathrm{pH}$ range is $6.6-7.0$ [8]. The analysis was performed daily during the experiment (figure 4).

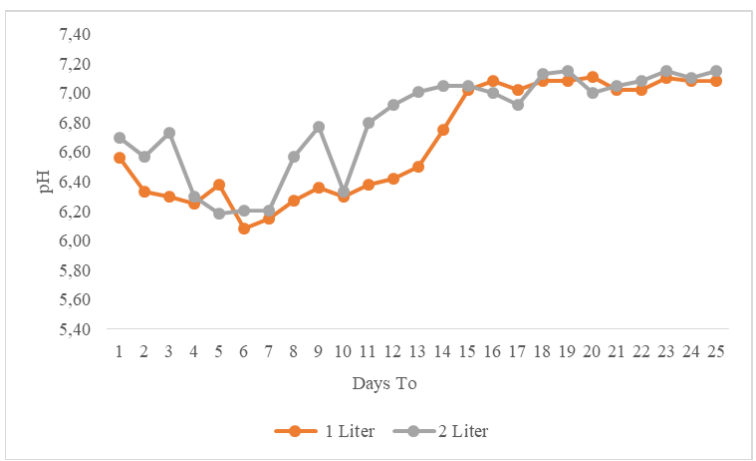

Fig. 4. Graph of $\mathrm{pH}$ Value.

The $\mathrm{pH}$ value in biogas production ranges from 6.5 to 7 . The resulting $\mathrm{pH}$ value is by the conditions required by methane-forming bacteria. If the $\mathrm{pH}$ drops below 6.2 , the methanogen bacteria will be poisoned, and consequently the biogas production will decrease [7].

\subsection{Analysis of biogas production}

To determine the volume of biogas produced, use the calculation of the ideal gas equation.

$$
\text { P.V = n.R.T }
$$

Where: 
- P: Pressure of the biogas.

- V: Volume

- $\quad$ n: Number of moles

- R: Specific gas constant. (8,314 J/mol.K)/ (0,082 L atm/mol.K)

- T: Temperature

Biogas production at two loadings was recorded daily and presented in the table as shown in (Table 1 and Table 2). Meanwhile (Figure 5) shows a graph of biogas volume for 25 days.

Table 1. Biogas production at additional loading of 1 liter.

\begin{tabular}{|c|c|c|c|c|c|}
\hline $\begin{array}{c}\text { Days } \\
\text { To }\end{array}$ & $\begin{array}{c}\text { Pressur } \\
\mathbf{e}\left(\mathbf{N} / \mathbf{m}^{2}\right)\end{array}$ & $\begin{array}{c}\text { Temperatur } \\
\mathbf{e}\left(\mathbf{}^{\circ} \mathbf{K}\right)\end{array}$ & $\mathbf{R}$ & $\begin{array}{c}\mathbf{M o l} \\
(\mathbf{n})\end{array}$ & $\begin{array}{c}\mathbf{V}=\mathbf{n R T} \mathbf{\text { P }} \\
\mathbf{( m}^{\mathbf{3}} \mathbf{)}\end{array}$ \\
\hline 1 & 101099 & 299,15 & $\begin{array}{c}0,08 \\
2\end{array}$ & 1 & $\begin{array}{c}0,0002426 \\
4\end{array}$ \\
\hline 2 & 101101 & 299,15 & $\begin{array}{c}0,08 \\
2\end{array}$ & 1 & $\begin{array}{c}0,0002426 \\
3\end{array}$ \\
\hline 3 & 101099 & 299,15 & $\begin{array}{c}0,08 \\
2\end{array}$ & 1 & $\begin{array}{c}0,0002426 \\
4\end{array}$ \\
\hline 4 & 101099 & 300,15 & $\begin{array}{c}0,08 \\
2\end{array}$ & 1 & $\begin{array}{c}0,0002434 \\
5\end{array}$ \\
\hline 5 & 101099 & 298,15 & $\begin{array}{c}0,08 \\
2\end{array}$ & 1 & $\begin{array}{c}0,0002418 \\
3\end{array}$ \\
\hline 6 & 101102 & 298,15 & $\begin{array}{c}0,08 \\
2\end{array}$ & 1 & $\begin{array}{c}0,0002418 \\
2\end{array}$ \\
\hline 7 & 101101 & 298,15 & $\begin{array}{c}0,08 \\
2\end{array}$ & 1 & $\begin{array}{c}0,0002418 \\
2\end{array}$ \\
\hline 8 & 101101 & 300,15 & $\begin{array}{c}0,08 \\
2\end{array}$ & 1 & $\begin{array}{c}0,0002434 \\
4\end{array}$ \\
\hline 9 & 101102 & 299,15 & $\begin{array}{c}0,08 \\
2\end{array}$ & 1 & $\begin{array}{c}0,0002426 \\
3\end{array}$ \\
\hline 10 & 101102 & 299,15 & $\begin{array}{c}0,08 \\
2\end{array}$ & 1 & $\begin{array}{c}0,0002426 \\
3\end{array}$ \\
\hline 11 & 101101 & 299,15 & $\begin{array}{c}0,08 \\
2\end{array}$ & 1 & $\begin{array}{c}0,0002426 \\
3\end{array}$ \\
\hline 12 & 101101 & 299,15 & $\begin{array}{c}0,08 \\
2\end{array}$ & 1 & $\begin{array}{c}0,0002426 \\
3\end{array}$ \\
\hline 13 & 101103 & 298,15 & $\begin{array}{c}0,08 \\
2\end{array}$ & 1 & $\begin{array}{c}0,0002418 \\
2\end{array}$ \\
\hline 14 & 101102 & 299,15 & $\begin{array}{c}0,08 \\
2\end{array}$ & 1 & $\begin{array}{c}0,0002426 \\
3\end{array}$ \\
\hline 15 & 101103 & 298,15 & $\begin{array}{c}0,08 \\
2\end{array}$ & 1 & $\begin{array}{c}0,0002418 \\
2\end{array}$ \\
\hline 16 & 101106 & 299,15 & $\begin{array}{c}0,08 \\
2\end{array}$ & 1 & $\begin{array}{c}0,0002426 \\
2\end{array}$ \\
\hline 17 & 101106 & 298,15 & $\begin{array}{c}0,08 \\
2\end{array}$ & 1 & $\begin{array}{c}0,0002418 \\
1\end{array}$ \\
\hline 18 & 101105 & 300,15 & $\begin{array}{c}0,08 \\
2\end{array}$ & 1 & $\begin{array}{c}0,0002434 \\
3\end{array}$ \\
\hline 19 & 101102 & 299,15 & $\begin{array}{c}0,08 \\
2\end{array}$ & 1 & $\begin{array}{c}0,0002426 \\
3\end{array}$ \\
\hline 20 & 101102 & 298,15 & $\begin{array}{c}0,08 \\
2\end{array}$ & 1 & $\begin{array}{c}0,0002418 \\
2\end{array}$ \\
\hline 21 & 101103 & 299,15 & $\begin{array}{c}0,08 \\
2\end{array}$ & 1 & $\begin{array}{c}0,0002426 \\
3\end{array}$ \\
\hline
\end{tabular}




\begin{tabular}{|c|c|c|c|c|c|}
\hline 22 & 101106 & 299,15 & $\begin{array}{c}0,08 \\
2\end{array}$ & 1 & $\begin{array}{c}0,0002426 \\
2\end{array}$ \\
\hline 23 & 101105 & 298,15 & $\begin{array}{c}0,08 \\
2\end{array}$ & 1 & $\begin{array}{c}0,0002418 \\
1\end{array}$ \\
\hline 24 & 101107 & 298,15 & $\begin{array}{c}0,08 \\
2\end{array}$ & 1 & $\begin{array}{c}0,0002418 \\
1\end{array}$ \\
\hline 25 & 101107 & 300,15 & $\begin{array}{c}0,08 \\
2\end{array}$ & 1 & $\begin{array}{c}0,0002434 \\
3\end{array}$ \\
\hline
\end{tabular}

Table 2. Biogas production at additional loading of 2 liter.

\begin{tabular}{|c|c|c|c|c|c|}
\hline $\begin{array}{c}\text { Day } \\
\mathbf{~ T o}\end{array}$ & $\begin{array}{c}\text { Pressur } \\
\mathbf{e}\left(\mathbf{N} / \mathbf{m}^{2}\right)\end{array}$ & $\begin{array}{c}\text { Temperatur } \\
\mathbf{e}\left({ }^{\mathbf{K})}\right.\end{array}$ & $\mathbf{R}$ & $\begin{array}{c}\mathbf{M o l} \\
(\mathbf{n})\end{array}$ & $\begin{array}{c}\mathbf{V}=\mathbf{n R T}(\mathbf{P} \\
\mathbf{( m}^{\mathbf{3}} \mathbf{)}\end{array}$ \\
\hline 1 & 101099 & 300,15 & 0,082 & 1 & $\begin{array}{c}0,0002434 \\
5\end{array}$ \\
\hline 2 & 101099 & 299,15 & 0,082 & 1 & $\begin{array}{c}0,0002426 \\
4\end{array}$ \\
\hline 3 & 101099 & 298,15 & 0,082 & 1 & $\begin{array}{c}0,0002418 \\
3\end{array}$ \\
\hline 4 & 101099 & 299,15 & 0,082 & 1 & $\begin{array}{c}0,0002426 \\
4\end{array}$ \\
\hline 5 & 101099 & 299,15 & 0,082 & 1 & $\begin{array}{c}0,0002426 \\
4\end{array}$ \\
\hline 6 & 101101 & 298,15 & 0,082 & 1 & $\begin{array}{c}0,0002418 \\
2\end{array}$ \\
\hline 7 & 101101 & 298,15 & 0,082 & 1 & $\begin{array}{c}0,0002418 \\
2\end{array}$ \\
\hline 8 & 101101 & 298,15 & 0,082 & 1 & $\begin{array}{c}0,0002418 \\
2\end{array}$ \\
\hline 9 & 101102 & 299,15 & 0,082 & 1 & $\begin{array}{c}0,0002426 \\
3\end{array}$ \\
\hline 10 & 101102 & 299,15 & 0,082 & 1 & $\begin{array}{c}0,0002426 \\
3\end{array}$ \\
\hline 11 & 101101 & 299,15 & 0,082 & 1 & $\begin{array}{c}0,0002426 \\
3\end{array}$ \\
\hline 12 & 101101 & 300,15 & 0,082 & 1 & $\begin{array}{c}0,0002434 \\
4\end{array}$ \\
\hline 13 & 101103 & 298,15 & 0,082 & 1 & $\begin{array}{c}0,0002418 \\
2\end{array}$ \\
\hline 14 & 101103 & 298,15 & 0,082 & 1 & $\begin{array}{c}0,0002418 \\
2\end{array}$ \\
\hline 15 & 101103 & 298,15 & 0,082 & 1 & $\begin{array}{c}0,0002418 \\
2\end{array}$ \\
\hline 16 & 101106 & 300,15 & 0,082 & 1 & $\begin{array}{c}0,0002434 \\
3\end{array}$ \\
\hline 17 & 101106 & 299,15 & 0,082 & 1 & $\begin{array}{c}0,0002426 \\
2\end{array}$ \\
\hline 18 & 101103 & 299,15 & 0,082 & 1 & $\begin{array}{c}0,0002426 \\
3\end{array}$ \\
\hline 19 & 101102 & 299,15 & 0,082 & 1 & $\begin{array}{c}0,0002426 \\
3\end{array}$ \\
\hline 20 & 101102 & 299,15 & 0,082 & 1 & $\begin{array}{c}0,0002426 \\
3\end{array}$ \\
\hline 21 & 101103 & 298,15 & 0,082 & 1 & $\begin{array}{c}0,0002418 \\
2\end{array}$ \\
\hline
\end{tabular}




\begin{tabular}{|c|c|c|c|c|c|}
22 & 101106 & 299,15 & 0,082 & 1 & $\begin{array}{c}0,0002426 \\
2\end{array}$ \\
\hline 23 & 101107 & 298,15 & 0,082 & 1 & $\begin{array}{c}0,0002418 \\
1\end{array}$ \\
\hline 24 & 101109 & 299,15 & 0,082 & 1 & $\begin{array}{c}0,0002426 \\
1\end{array}$ \\
\hline 25 & 101109 & 299,15 & 0,082 & 1 & $\begin{array}{c}0,0002426 \\
1\end{array}$ \\
\hline
\end{tabular}

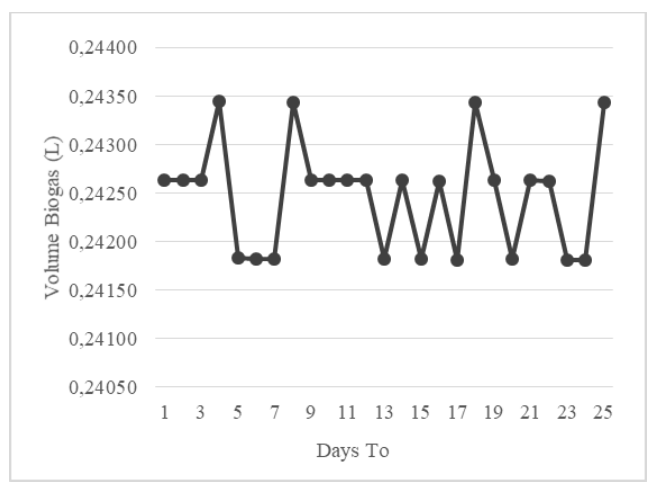

(a)

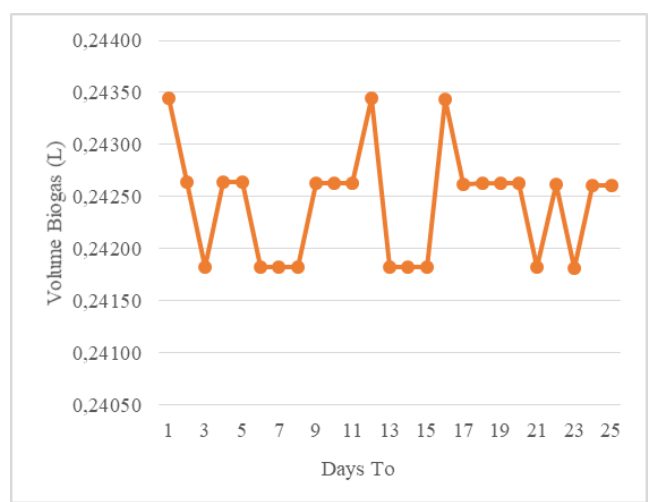

(b)

Fig. 5. Graph of biogas volume loading 1 liter (a) and loading 2 liter (b).

\section{Conclusion}

Biogas production using palm oil mill effluent (POME) and the addition of cow dung in a fixed bed type bio-digester can increase biogas production. The results of the pressure analysis show the results of a very significant increase in pressure. These changes occur due to the presence of micro-bacteria that have formed in the digester [9]. The optimal loading rate is found in the 1 liter/day treatment, which produces a biogas volume of 6.1 liters for 25 days. This condition occurs due to excessive accumulation of organic matter, causing bacteria to be unable to break down organic compounds to disrupt the anaerobic breakdown process [10]. Thus, the results of this experiment can provide helpful information for the future in the appropriate waste treatment process, especially in the production of biogas from 
POME and the production of sustainable renewable energy to encourage the fulfillment of low-carbon systems and technologies.

\section{Acknowledgement}

This publication is an output of KEDAIREKA project "Pengembangan Integrated Farming System untuk Menunjang Energi dan Pertanian Berkelanjutan" which is financially supported by Directorate General of Higher Education, The Ministry of Education, Culture, Research and Technology through Matching Fund 2021 Under Agreement Nr: 2183/E3/PKS.06/KL/2021.

\section{References}

1. Mielke, Thomas, Oil World, 1-41(2018)

2. Sardjono, Mukti, GAPKI, (2021)

3. K. Gobi, V.M. Vadivelu, Renewable and Sustainable Energy Reviews, 788-803, (2013)

4. W. Sih winanti, Prasetiyadi, Wiharja, Jurnal Teknologi Lingkungan, 20, 1, (2019)

5. T. Emilia Agustina, B. Sulistyono, R. Anugrah, Jurnal Teknik Kimia, 22, 3, (2016)

6. U. Werner, U. Stöhr, N. Hees, Biogas plants in animal Husbandry press, (1989).

7. Suyitno, A. Sujono, Dharmanto, Teknologi Biogas press, (2010).

8. Ir. Ambar Pertiwiningrum, M. P. Instalasi Biogas. Yogyakarta: CV. Kolom Cetak (2016)

9. Felix Dionisus, M. E. Karakteristik. Prosiding. 24-27 (2019)

10. Mahajoeno, E. Pengembangan energi terbarukan dari limbah cair pabrik minyak kelapa sawit. Disertasi. Program Studi Pengelolaan Sumber Daya Alam dan Lingkungan, Institut Pertanian Bogor (2008) 